http://jmscr.igmpublication.org/home/

ISSN (e)-2347-176x ISSN (p) 2455-0450

crossref DOI: https://dx.doi.org/10.18535/jmscr/v8i6.68

\title{
Prevalence of various causes of infectious keratitis among patients coming to OPD of Katihar Medical College Hospital and its visual outcome: A prospective observational study
}

\author{
Authors \\ Dr Himanshu Kumar ${ }^{1}$, Dr Arjun Kumar Singh ${ }^{2 *}$ \\ ${ }^{1}$ Assistant Professor, Department of Ophthalmology, Katihar Medical College, Katihar, Bihar \\ ${ }^{2}$ Associate Professor, Department of Ophthalmology, Katihar Medical College, Katihar, Bihar \\ *Corresponding Author \\ Dr Arjun Kumar Singh \\ A/39 PC Colony Opposite to Arun Jeitly Park Kankarbagh Patna 800020, Bihar, India
}

\section{Introduction}

Corneal infection is the most common cause of monocular corneal blindness worldwide. ${ }^{[1]}$ The ocular trauma and corneal ulceration results in 1.5-2 million new cases of corneal blindness annually. ${ }^{[2]}$ As per recent worldwide lists on the causes of blindness, corneal opacity is the secondmost common cause of blindness and visual disability in developing countries. ${ }^{[3],[4]}$ Corneal blindness due to keratitis is a major public health problem in India. The most common causes of corneal blindness are infections made worse by the lack of proper nutrition due to poverty and illiteracy. Ulcerative keratitis must be considered as an ocular emergency. Early recognition with prompt diagnosis and rapid institution of appropriate therapy will significantly improve visual prognosis.

This study was undertaken to evaluate current status, the incidence of infectious keratitis in this part of rural central India and its visual morbidity.

\section{Materials and Methods}

It was a prospective observational hospital-based study conducted at the Department of Ophthalmology, at a tertiary care hospital, in Katihar, Bihar India. The study was conducted with the approval of the Institutional Ethics committee with proper consent taken from the patients.

Inclusion criteria were patients with infectious keratitis, also patients on the treatment of infectious keratitis with irregular follow-up.

Exclusion criteria were patients showing signs and symptoms of endophthalmitis and panophthalmitis. Appropriate history was taken to find out predisposing factors, previous treatment, and duration of symptoms. Visual acuity was recorded at the time of presentation. All patients were evaluated on slit lamp to record the size, depth, and location of ulcer along with an examination of margins, floor, and infiltrations. Examination of ocular adnexa including lids, eyelashes, and lacrimal sac area was done. The sac syringing was done to check the patency of the lacrimal system, and random blood sugar was 
recorded to screen for diabetes mellitus in every patient. Corneal scraping was done in cases of large epithelial defect and involved visual axis. A nonpreservative topical anesthetic was instilled (proxymetacaine $0.5 \%$ ). Scrapping was taken with a disposable scalpel blade. Loose mucus and necrotic tissue were removed before scraping. The margins and base of the lesion were scraped. The thin smear was placed on one or two glass slide for microscopy, including gram stain, Giemsa, acid-fast bacillus, calcofluor white. ${ }^{[8]}$

\section{Results}

During the period of January 2019 to January 2020 , a total of 68 were diagnosed with infective keratitis and were included in the study. The mean age of the patient was 46 years. Majority of patients of infectious keratitis were in between 41 and $60(46 \%)$ age group followed by $21-40(21 \%)$ and incidence in male was higher than $(61 \%)$ that of female. The left eye was slightly more commonly involved (64\%) as compared to the right eye $(36 \%)$.

Distribution of patient according to occupation shows majority cases (42.04\%) were farmer followed by household work (29.54\%) and laborer $(15.90 \%)$. Miserable amount patients among business (2.27\%), students/children (6.81\%) and $3.40 \%$ were others.

The incidence of fungal keratitis (47 cases, $69.11 \%$ ) was higher than bacterial (15 cases, $22.05 \%)$ and viral (6 cases, $8.82 \%)$. Out of 68 , fresh cases were $43(63.23 \%), 8(11.76 \%)$ patients were on antimicrobial and 17 on self medication on steroid $(25 \%)$.

$14.70 \%$ (10 cases) had significant visionthreatening complication noted at the time of presentation and during management. It includes secondary glaucoma occurred due to fibrinous exudates $10.29 \%$ ( 7 cases), iridiocyclitis $4.41 \%$ (3 cases) and While 58 cases $(85.29 \%)$ had less significant vision-threatening such as corneal scar, mild iridocyclitis, and mild raised intraocular pressure (IOP) which was controlled on topical anti-glaucoma medication.
On prompt follow-up and appropriate treatment most of the corneal ulcer healed.41\% had improved BCVA whereas $53 \%$ had stable BCVA compare to BCVA at the time of presentation. Only $6 \%$ deteriorated mainly due to poor followup and compliance.

\section{Discussion}

Clinical outcome in microbial keratitis and epidemiological patterns may be different from country to country and between different geographical regions within a country. In our study, Majority of patients of infectious keratitis were in between 41 and 60 (46\%) age group followed by $21-40(21 \%)$. Most of them were a farmer as this is the most common occupation of rural population in developing countries. This explains why agriculture trauma was the leading predisposing factor of corneal ulcer in developing countries. ${ }^{[9]}$

Incidence was higher in males $(61 \%)$ than that of females in our study. Male predominance was found in many studies, ${ }^{[10],[15]}$. This may be because males are more involved in outdoor activities and also males are preferred over females to seek medical advice.

Out of the 68 patients with corneal ulcer, the detection of fungal filaments in $10 \% \mathrm{KOH}$ mount has $90 \%-99 \%$ sensitivity. ${ }^{[18]}$ While sensitivity and specificity of bacterial detection in gram stain are inferior to that of culture method. ${ }^{[19]}$ Fungal isolates $(59.09 \%)$ were more common in this study than bacterial isolates (42.08\%), followed by Aspergillus spp., was the most commonly isolated fungal pathogen in this study. Srinivasan et $a l .{ }^{[10]}$ show the similar to the findings, while other studies have reported Aspergillus spp.

Lack of awareness and local treatment from nonophthalmologist were responsible for late presentation and severe complications.

Majority of patients came to our hospital were from the nearby rural region. Most of them take initial treatment from the local practitioner including paramedical and medical personnel, 
relatives, traditional healer, and even directly from drugstores. On prompt follow-up and appropriate treatment most of the corneal ulcer healed.

\section{Conclusion}

The incidence of fungal corneal ulcer is higher among various causes of infectious keratitis in the part of rural central India. Agricultural injuries are the main predisposing factor for infectious keratitis in this region. Prompt diagnosis and early appropriate treatment on the basis of laboratory investigation can helps the community to reduce the burden of corneal blindness. Community awareness of the risk factors and restriction of the abuse of topical corticosteroids or antibiotics plays a key role for control worsening of diseases.

\section{References}

1. Chirambo MC, Tielsch JM, West KP Jr., Katz J, Tizazu T, Schwab L, et al. Blindness and visual impairment in Southern Malawi. Bull World Health Organ 1986;64:567-72.

2. Pascolini D, Mariotti SP. Global estimates of visual impairment: 2010. $\mathrm{Br} \mathrm{J}$ Ophthalmol 2012;96:614-8.

3. Whitcher JP, Srinivasan M, Upadhyay MP. Corneal blindness: A global perspective. Bull World Health Organ 2001;79:214-21.

4. Jonas JB, Xu L, Wang YX. The beijing eye study. Acta Ophthalmol 2009;87:24761.

5. Population Census of India; 2011. Available from: http://www.//2011common/censusData2011.html.

6. Kuper H, Polack S, Limburg H. Rapid assessment of avoidable blindness. Community Eye Health 2006;19:68-9.

7. NPCB. Managing Corneal Blindness. India: NPCB; April-June, 2012.

8. Sharma S, Kunimoto DY, Gopinathan U, Athmanathan S, Garg P, Rao GN, et al. Evaluation of corneal scraping smear examination methods in the diagnosis of bacterial and fungal keratitis: A survey of eight years of laboratory experience. Cornea 2002;21:643-7.

9. Panda A, Satpathy G, Nayak N, Kumar S, Kumar A. Demographic pattern, predisposing factors and management of ulcerative keratitis: Evaluation of one thousand unilateral cases at a tertiary care centre. Clin Exp Ophthalmol 2007;35:4450.

10. Khare P, Shrivastava M, Kumar K. Study of epidemiological characters, predisposing factors and treatment outcome of corneal ulcer patients. Int $\mathbf{J}$ Med Res Rev 2014;2:33-9.

11. Srinivasan M, Gonzales CA, George C, Cevallos V, Mascarenhas JM, Asokan B, et al. Epidemiology and aetiological diagnosis of corneal ulceration in Madurai, South India. Br J Ophthalmol 1997;81: 965-71.

12. Reddy PS, Satyendran OM, Satapathy M, Kumar HV, Reddy PR. Mycotic keratitis. Indian J Ophthalmol 1972;20:101-8.

13. Bharathi MJ, Ramakrishnan R, Vasu S, Meenakshi, Palaniappan R. Aetiological diagnosis of microbial keratitis in South India - A study of 1618 cases. Indian J Med Microbiol 2002;20:19-24.

14. Bourcier T, Thomas F, Borderie V, Chaumeil C, Laroche L. Bacterial keratitis: Predisposing factors, clinical and microbiological review of 300 cases. $\mathrm{Br} \mathbf{J}$ Ophthalmol 2003;87:834-8.

15. Gonzales CA, Srinivasan M, Whitcher JP, Smolin G. Incidence of corneal ulceration in Madurai district, South India. Ophthalmic Epidemiol 1996;3:159-66.

16. Bharathi MJ, Ramakrishnan R, Vasu S, Meenakshi R, Shivkumar C, Palaniappan $\mathrm{R}$, et al. Epidemiology of bacterial keratitis in a referral centre in South India. Indian J Med Microbiol 2003;21:239-45.

17. Chander J, Singla N, Agnihotri N, Arya SK, Deep A. Keratomycosis in and around 
Chandigarh: A five-year study from a North Indian tertiary care hospital. Indian J Pathol Microbiol 2008;51:304-6.

18. Vajpayee RB, Angra SK, Sandramouli S, Honavar SG, Chhabra VK. Laboratory diagnosis of keratomycosis: Comparative evaluation of direct microscopy and culture results. Ann Ophthalmol 1993;25:68-71.

19. Wahl JC, Katz HR, Abrams DA. Infectious keratitis in Baltimore. Ann Ophthalmol 1991;23:234-7.

20. Basak SK, Basak S, Mohanta A, Bhowmick A. Epidemiological and microbiological diagnosis of suppurative keratitis in gangetic West Bengal, Eastern India. Indian J Ophthalmol 2005;53:17-22.

21. Deorukhkar S, Katiyar R, Saini S. Epidemiological features and laboratory results of bacterial and fungal keratitis: A five-year study at a rural tertiary-care hospital in Western Maharashtra, India. Singapore Med J 2012;53:264-7.

22. Kumari N, Xess A, Shahi SK. A study of keratomycosis: Our experience. Indian $\mathrm{J}$ Pathol Microbiol 2002;45:299-302.

23. Kotigadde S, Ballal M, Jyothirlatha, Kumar A, Srinivasa R, Shivananda PG, et al. Mycotic keratitis: A study in coastal Karnataka. Indian J Ophthalmol 1992;40:31-3. 